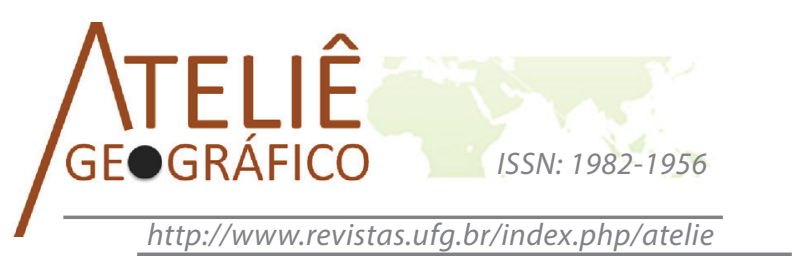

\title{
Uso religioso de cavernas no Sudeste Asiático e China: a paisagem cárstica sob outra perspectiva
}

\section{The religious use of caves in Southeast Asia and China: the karst landscape under another perspective}

\section{Uso religioso de cuevas en el sudeste asiático y China: paisaje carsica desde otra perspectiva}

\author{
Liz Price \\ União Internacional de Espeleologia \\ lizprice@hotmail.com \\ Luiz Eduardo Panisset Travassos \\ PUC Minas \\ luizepanisset@gmail.com
}

\begin{abstract}
Resumo
A relação entre o ser humano e as cavernas apresenta um caráter multifacetado. Além do uso de tais espaços para abrigo e proteção, outro tipo de uso que se destaca como igualmente importante é o espiritual e/ou religioso. Desde os tempos mais remotos o subterrâneo tem sido utilizado como templos, seja de forma incipiente ainda na pré-história, seja em períodos mais modernos na história. Independente das motivações envolvidas, cavernas naturais ou artificiais distribuem-se por todo o mundo e em todos os continentes. Dessa forma, o presente trabalho objetiva destacar exemplos de uso religioso de cavernas no Sudeste Asiático e China e de que forma fazem parte da história daquela região.
\end{abstract}

Palavras-chave: cavernas; religião; história; Sudeste Asiático; China.

\begin{abstract}
The relationship between humans and caves presents a multifaceted character: besides the use of such spaces for shelter and protection, another type of use that stands out as equally important is the spiritual and/or religious one. The underground has been used as temples since the earliest times, still incipient in prehistory but more elaborate in modern periods in history. Regardless of the motivation involved,
\end{abstract}


natural or artificial caves are spread throughout the world and on every continent. Thus, this study aims at highlighting examples of the religious use of caves in Southeast Asia and China that show how they are part of the history of that region. Keywords: caves, religion, history, Southeast Asia, China.

\begin{abstract}
Resumen
La relación entre los humanos y las cuevas presenta un carácter multifacético. Además del uso de dichos espacios en busca de refugio y protección, otro uso que se destaca por ser igualmente importante es la espiritual y/o religiosa. Desde los primeros tiempos el subterráneo se ha utilizado como templos aún incipiente en la prehistoria, o de manera más elaborada en períodos más modernos de la historia. Independientemente de las motivaciones que intervienen, cuevas naturales o artificiales se extienden por todo el mundo y en todos los continentes. Así, este estudio tiene como objetivo poner de relieve ejemplos de uso religioso de las cuevas en el sudeste de Asia y China, y la forma en que son parte de la historia de esa región.
\end{abstract}

Palabras clave: cuevas, religión, historia, sudeste de Asia, China.

\title{
Introdução
}

Em várias partes do mundo existem evidências materiais que elevam as cavernas a posições de destaque na História Mundial. Destacam-se como espaços que são utilizados para práticas contemplativas, meditação e elevação espiritual. Na verdade, em muitas crenças, importantes figuras religiosas passaram parte de suas vidas em cavernas fazendo com que tais lugares se tornassem muito importantes para suas religiões. Diniz et al. (2013) afirmam que existem fortes evidências históricas que registram o fato de que Sidarta Gautama, o fundador do Budismo, teria passado momentos decisivos de sua vida em uma caverna e lá teria meditado sobre a natureza do sofrimento humano. Assim, a prática da meditação dentro de cavernas tornou-se extremamente relevante ao Budismo, fato que deu início ao processo de construção de numerosos templos em cavernas pelo mundo ao longo dos últimos 2.500 anos.

Dessa forma, o presente trabalho busca registrar alguns exemplos de uso histórico-religioso de cavernas no Sudeste Asiático, em especial, na Malásia, Camboja, Myanmar e na China. O trabalho baseou-se em trabalhos de campo dos autores, bem como em literatura sobre o tema.

A região oficialmente conhecida como Sudeste Asiático é composta por países que estão geograficamente localizados ao sul da China, leste da Índia e norte da Austrália. É dividia em duas regiões principais: a primeira, como parte do continente asiático, é conhecida como Indochina e a segunda, é formada pelas ilhas de leste e sudeste. Assim, tem-se a porção continental composta pelo Camboja, Laos, Myanmar, Tailândia, Vietnã e Malásia Peninsular, enquanto que a porção insular é composta por Bornéu (Brunei, 
Leste da Malásia e o Kalimantan Ocidental), Timor Leste, Papua Nova Guiné, Filipinas e Singapura (Figura 1).

O carste regional, segundo Mouret (2004), caracteriza-se como um importante fenômeno natural na porção continental. Myanmar, Tailândia, Laos, Vietnã, Camboja e a Malásia Peninsular apresentam significativas áreas carbonáticas que perfazem cerca de $10 \%$ da região, ou $215.000 \mathrm{Km}^{2}$. Já a China, de acordo com Yuan (1991), apresenta cerca de $500.000 \mathrm{~km}^{2}$ de carste conforme destacado na figura 1. Por esse motivo, é de se esperar que suas cavernas fossem amplamente utilizadas pelo homem desde a préhistória até o presente.

Embora a própria região sul da China não seja considerada formalmente o "sudeste asiático", optou-se por incluir no trabalho algumas cavernas-templo existentes na Região Autônoma Zhuang de Guangxi devido à sua proximidade geográfica, bem como ao seu uso religioso histórico. Por causa da extensão, escala e variedade de seu carste, a China viu nascer importantes pensadores que descreveram e buscaram compreender melhor os fenômenos cársticos regionais. Esse foi o caso, por exemplo, de Xu Xiake (1587-1641), importante geógrafo viajante chinês dos séculos XVI e XVII (Fig. 2).

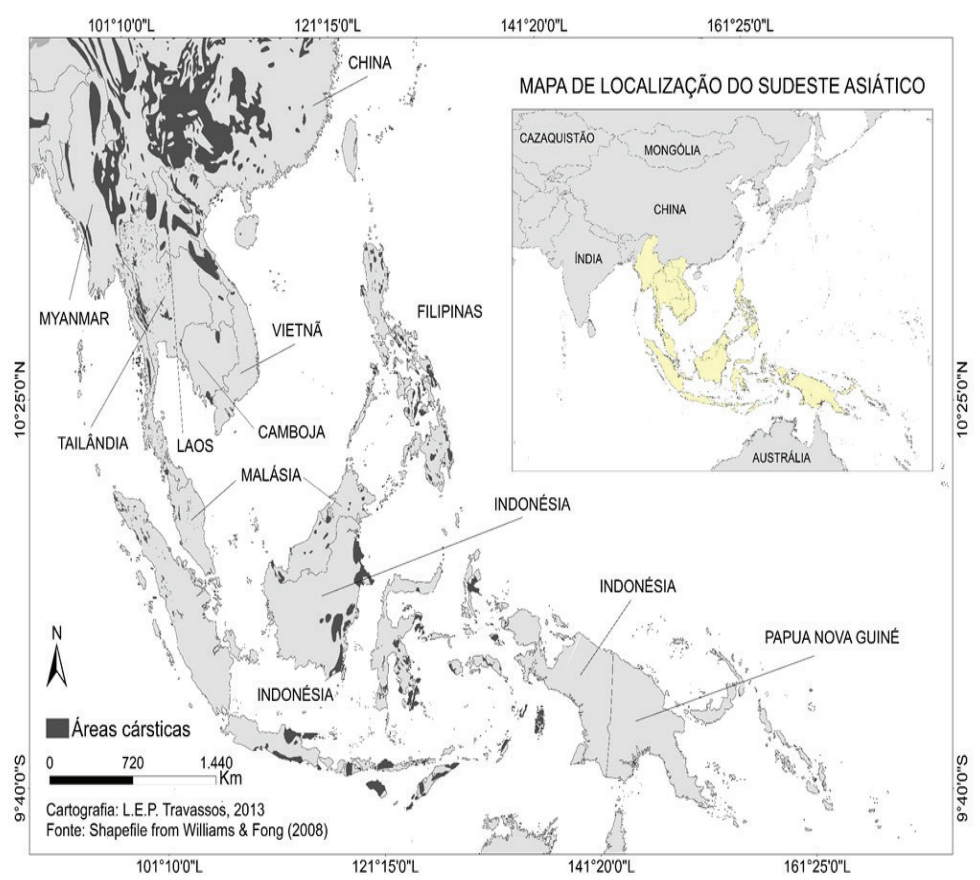

Figura 1. Mapa de distribuição do carste do Sudeste Asiático e parte da China. 

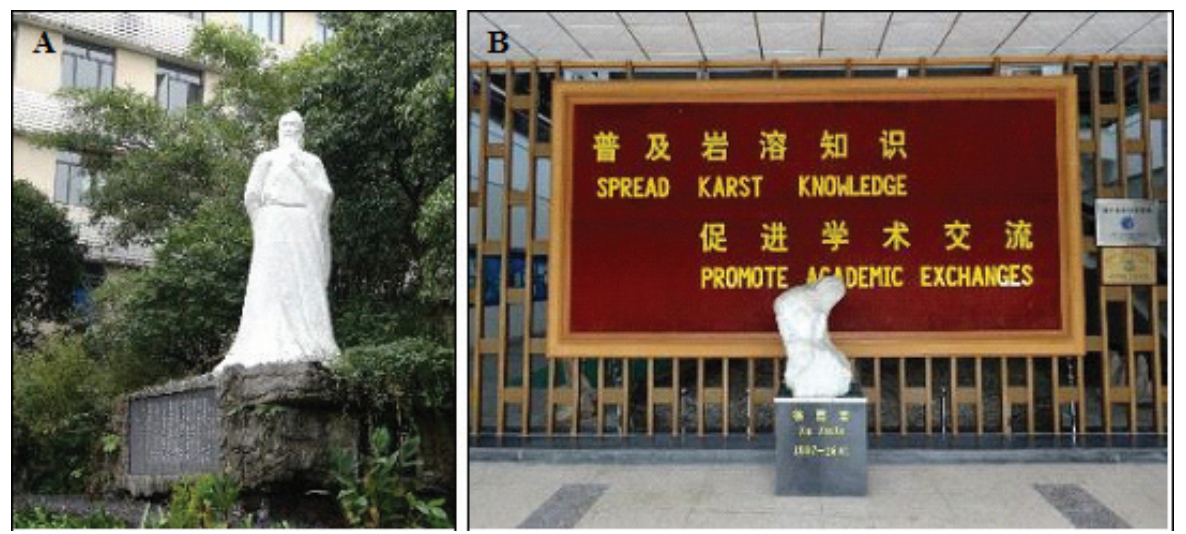

Figura 2. A) Escultura em homenagem à Xu Xiake em frente ao prédio do International Research Center on Karst, em Guilin, China. A imagem 'B' mostra os dizeres na entrada do Museu do Carste nos limites do Centro de Pesquisas retratando o espírito daquele geógrafo chinês e do Centro: "Divulgar o conhecimento sobre o carste e promover intercâmbios acadêmicos".

Fotos: L. E. P. Travassos.

\section{Aspectos religiosos do Sudeste Asiático e China}

Sob o aspecto religioso, destaca-se que várias religiões são praticadas na região. O Islã é a religião com o maior número de adeptos no sudeste asiático, com cerca de $40 \%$ da população, especialmente no Brunei, Indonésia e Malásia. Com relação ao uso do subterrâneo pelos praticantes, Andreychouk, Travassos e Barbosa (2010) afirmam que, para muitos de seus praticantes, a adoração de uma paisagem específica ou de uma feição geológica parece ser inaceitável, salvo a adoração à caverna de Hira, considerada sagrada, pois foi o local onde o Profeta Maomé teria recebido as revelações divinas. Entretanto, mesmo que as cavernas sagradas não apareçam com frequência, sabe-se da existência de cavernas consideradas sagradas por grupos muçulmanos locais em diversas partes do mundo.

Em relação ao Budismo, destaca-se o grande número de praticantes na China, Tailândia, Camboja, Laos, Myanmar e Vietnã. Embora a Malásia seja predominantemente muçulmana, identificam-se praticantes do Hinduísmo e do Budismo, além do Cristianismo e outras formas de religião como o Confucionismo e o Taoísmo. Destaca-se que Singapura apresenta maioria Budista, com cerca de 42,5 \% de sua população total de acordo com os dados do senso de 2000 fornecidos pelo Governo da Singapura em 2013.

Sobre o Budismo, Diniz et al. (2013) afirmam que essa religião pode ser considerada como uma família de filosofias com forte presença na Ásia. É capaz de incorporar diversos aspectos das culturas locais e, assim, produzir uma vasta gama de "escolas". Por esse motivo, calcular o número de praticantes por país é tarefa extremamente complexa devido a alguns fatores. Entre eles está o fato de que muitos praticantes de religiões orientais geralmente praticam uma espécie de combinação entre 
o budismo, animismo, confucionismo, taoísmo e xintoísmo, por exemplo. Entretanto, para Robinson (2011), o número de praticantes do budismo no mundo atinge cerca de $6 \%$ da população, número que não é desprezível, embora seja pequeno se comparado ao Cristianismo (32\%), Islamismo (19\%) e Hinduísmo (13\%).

De todos os países mencionados neste trabalho, com exceção do Islã, as demais religiões utilizam cavernas como templos desde os tempos mais remotos sendo, portanto, importantes fontes de informações arqueológicas e etnológicas.

A experiência nos mostra que as cavernas-templo budistas, geralmente, são as mais abundantes no Sudeste Asiático e China, fato também comprovado por Diniz et al. (2013). Entretanto, existem cavernas hinduístas, cujo exemplo mais famoso é o das Cavernas Batu. Algumas das cavernas são simples, enquanto outras são muito mais bem decoradas e modificadas.

Mesmo que na região também seja comum a descoberta de cavernas com vestígios arqueológicos que datam do Paleolítico ao Neolítico, acredita-se que seu uso religioso seja um fenômeno muito mais recente. Um dos registros mais antigos no Sudeste Asiático é a da Caverna Kawgon (Kogun), em Kayin, Myanmar, que apresenta estátuas e inscrições budistas do século XVII. Destaca-se que, durante o período colonial, a caverna era conhecida como Kogun, bem como a Caverna dos Dez Mil Budas (TEMPLE, 1894; GLOVER; PRICE, 2004). Já no sudeste chinês, especialmente em Guilin, existem cavernas transformadas em templos budistas desde a Dinastia Tang (618-907 d.C.).

Destaca-se que o carste presente nos países do Sudeste Asiático e China é tipicamente tropical e pode ser classificado em dois tipos principais: 1) o cone karst ou carste em cone e 2) o tower karst ou carste em torre. Waltham (2008) afirma que os geomorfólogos chineses distinguem o tipo de carste do país não pela forma de suas colinas, mas pela presença ou não de planícies entre elas. Assim sendo, em campo, percebe-se que no carste em cone (Fengcong - 'agrupamento de picos') não são comuns cones isolados e, sim, seus agrupamentos que são separados por profundas depressões fechadas. Individualmente, tais cones apresentam elevações que variam dos 30 aos 500 metros (Figura 3).

Já no tipo de paisagem conhecida como carste em torre (Fenglin - 'floresta de picos'), a paisagem é marcada por torres calcárias, planícies e cavernas que podem estar localizadas no alto destas "torres", ora como templos e mosteiros, ora como locais mais simples que também são visitados. Sweeting (1990), Yuan (1991) e Waltham (2008) destacam que o carste em torre é uma paisagem onde colinas isoladas aparecem em meio a uma grande planície cárstica. Waltham (2008) ainda afirma que esse tipo de paisagem é quase totalmente restrito ao carste do Sudeste Asiático, estendendo-se de forma mais ou menos contínua desde Guangxi (China) até o nordeste do Vietnã e, descontinuamente, no resto do Vietnã, Tailândia, Burma e Indonésia. Destaca-se que as grandes planícies entre as torres são geralmente ocupadas por campos cultivados, vilas ou cidades (Figura 4). 


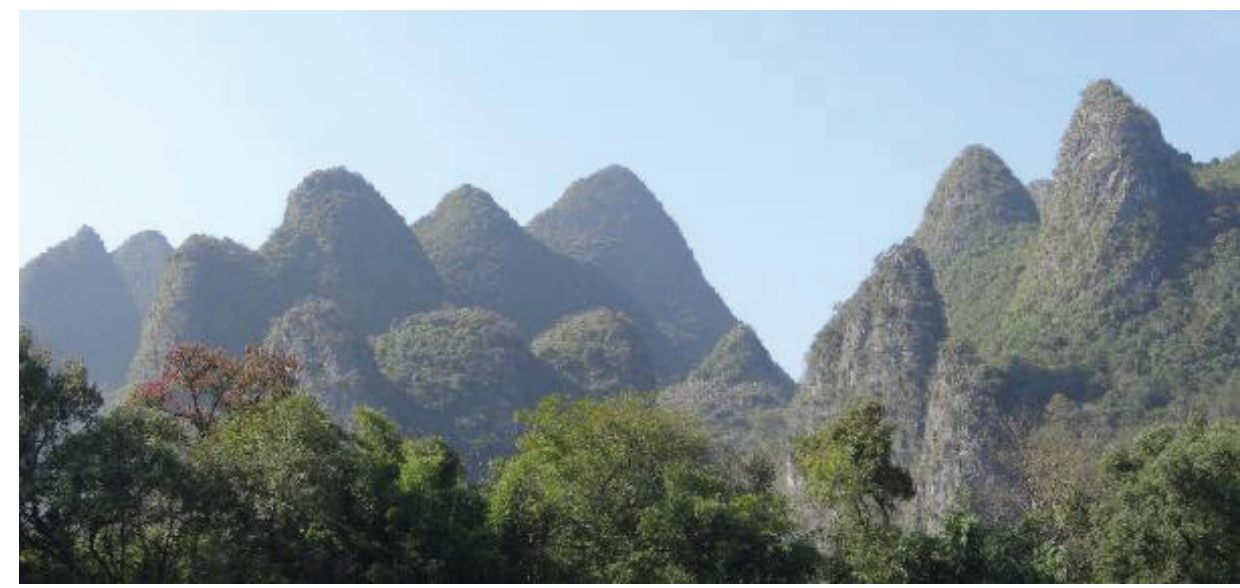

Figura 3. Aspectos gerais do carste em cone, conhecido como Fengcong, ao longo do rio Li, em Guangxi, China. Observa-se que as torres não apresentam grandes planícies entre elas. Fotos: L. E. P. Travassos.

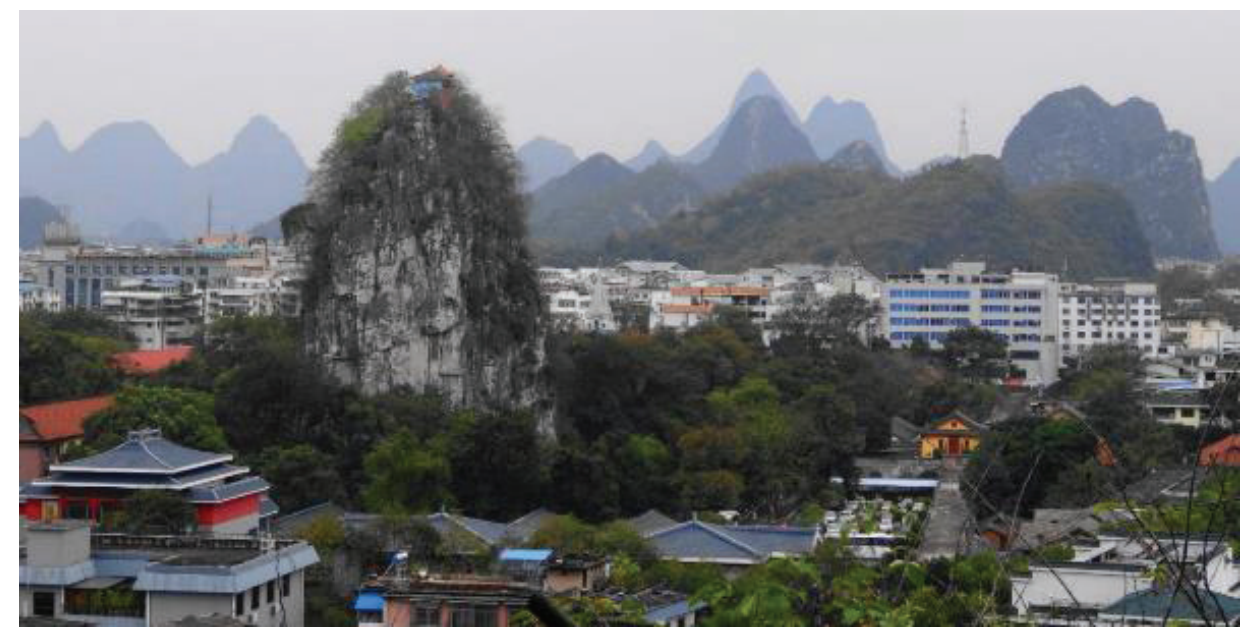

Figura 4. A cidade de Guilin, na China, desenvolve-se em meio a um carste do tipo Fenglin. Na imagem é possível perceber um templo no topo do Solitary Beauty Peak, sítio onde se localizava o palácio do Príncipe Jingjiang, durante a Dinastia Ming, 1368-1644.

Foto: L.E.P.Travassos.

Para Humphreys citado por Diniz et al. (2013), as três maiores escolas do Budismo são a Theravada, a Mahayana e a Escola Tibetana. Todas apresentam diferentes formas de expressar os ensinamentos de Buda e acredita-se que a separação das escolas remonta ao ano 383 a.C. quando o Segundo Conselho Budista, ocorrido na Índia, demandou o relaxamento das práticas monástica em função dos crescentes conflitos em 
torno das interpretações dos ensinamentos de Buda. Para a escola mais tradicional, a Theravada, Buda teria sido um ser humano que atingiu a iluminação, algo possível desde que os monges e praticantes sigam as regras estabelecidas durante o Primeiro Conselho Budista.

É justamente o Budismo Theravada o mais comum no Camboja, Laos, Myanmar, Tailândia e pequenas partes da China. Em alguns casos, existem seguidores que renunciam seu modo de vida "mundano" para viver na floresta e meditar. Em muitas dessas áreas, os praticantes utilizam as cavernas como moradia. Na China observa-se o crescimento mais expressivo do Budismo a partir da Dinastia Tang (618 $\square 907$ d. C.) e os registros relacionados às cavernas mais conhecidos são aqueles das cavernas de Mogao, Longmen e Yungang, embora saiba-se que dinastias anteriores já reconheciam a religião. Neste país tem-se comumente a Escola Mahayana e Vajrayana e seus desdobramentos.

\section{Exemplos selecionados}

Nos países visitados, notaram-se certas características comuns em relação ao uso das cavernas. Tais semelhanças vão desde a estrutura turística de visitação, até mesmo a escala. A seguir foram destacados alguns exemplos.

\section{Malásia}

De maneira geral, Annandale, Coggin Brown e Gravely (1913) destacam o fato de que o país apresenta uma paisagem onde torres ou colinas isoladas de calcários se sobressaem em uma paisagem plana, dominada ou adequada para agricultura. Nos maciços encontram-se muitas cavernas em sua base ou na meia encosta.

As cavernas encontradas nestes afloramentos raramente penetram profundamente no maciço, tornando-se lugares adequados para a construção dos templos, visto que a luz penetra facilmente em seu interior e poucos esforços são feitos para iluminar artificialmente o templo.

No tocante à religião dominante, a Malásia é considerada um país bem diferente se comparado a outros do Sudeste Asiático, pois o Islã é a crença dominante. Ainda assim inúmeras cavernas budistas, bem como outros templos, foram erigidos pela população chinesa que se instalou na região a partir do século XV. Entretanto, o exemplo mais conhecido é o das Cavernas Batu, que é um sítio Hinduísta. O templo consiste em três cavernas principais e uma série de outras secundárias e menores que, de acordo com Kiernan (2004), são visitadas por mais de 800.000 pessoas durante o Festival de Thaipusam que ocorre todos os anos no país.

Gaarder, Hellern e Notaker (2005, p. 44) registram que diferentemente do Budismo, do Cristianismo e do Islã, o Hinduísmo não tem um fundador nem um credo fixo. Por esse motivo é uma religião caracterizada por uma "imensa diversidade e capacidade de abranger novos modos de pensamento e expressão religiosa". Suas 
raízes podem ser encontradas "entre o ano 1.500 a.C. e o ano 2.000 a.C." (GAARDER; HELLERN; NOTAKER, 2005, p.44).

Durante as comemorações os devotos demonstram respeito à deidade Lord Subramaniam em uma combinação de agradecimento, fervor devocional e sacrifício. O Thaipusam é celebrado em noite de lua cheia durante o décimo mês Hindu (Thai), normalmente entre 14 de janeiro a 14 de fevereiro. Embora celebrado em vários estados, o sítio mais famoso é o das Cavernas Batu, localizadas $12 \mathrm{~km}$ ao norte da capital Kuala Lumpur. A caverna principal, chamada de Caverna Templo (Temple Cave), é dedicada a Subramaniam. Como parte dos rituais os devotos realizam a Kavadi que, de acordo com a tradição, consiste em duas peças semicirculares de madeira ou aço que são dobradas e conectadas a uma estrutura que se equilibra nos ombros do indivíduo. A estrutura é, então, presa no corpo do devoto por meio de ganchos que perfuram o corpo. Outros fiéis podem perfurar bochechas e línguas com grandes agulhas de metal ou prender sinos, flores e frutas com ganchos presos à pele como parte dos rituais de purificação. A partir da rua principal, os participantes sobem os 272 degraus que levam até o interior do templo principal, onde deixam as oferendas e agradecem ao seu Deus. Na base da escadaria principal está localizada uma estátua dourada de Lord Murugan com cerca de 42,7 metros de altura e considerada a maior estátua desta deidade localizada fora de um templo calcário (Figura 5).
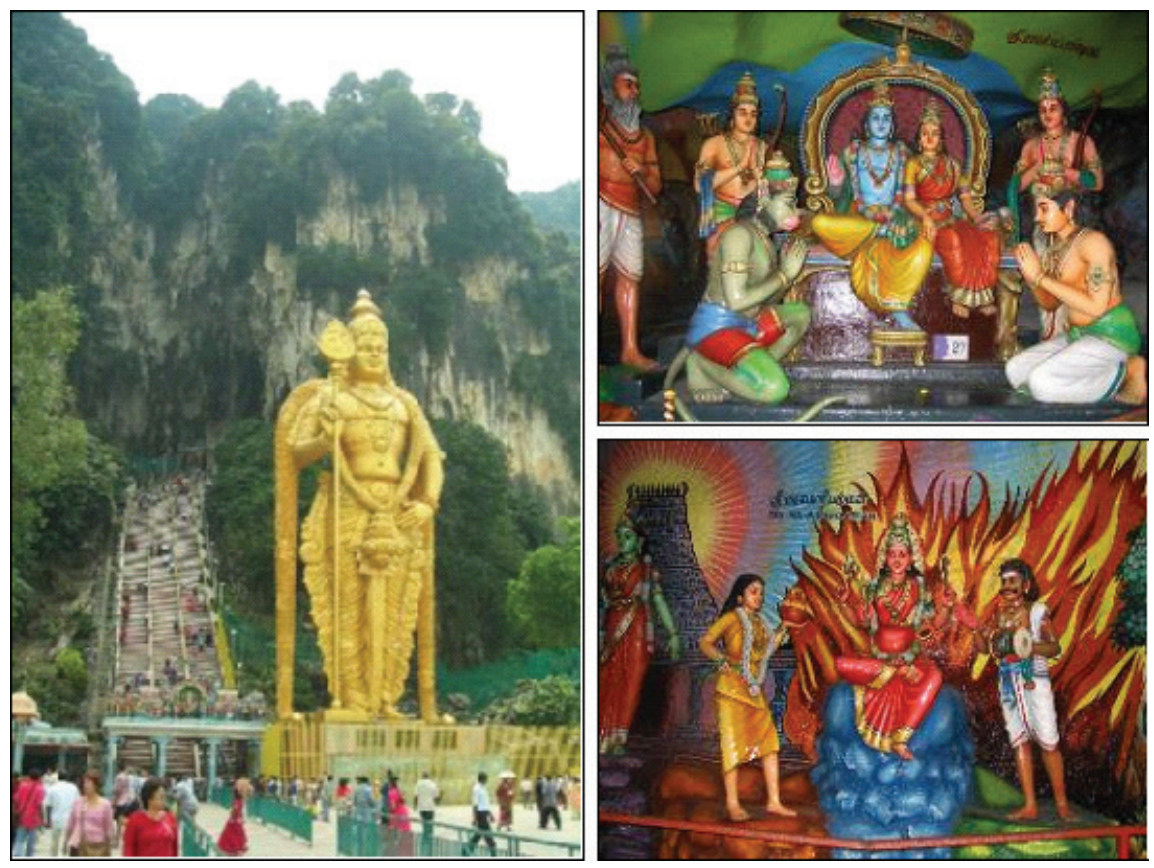

Figura 5. A) Estátua de Lord Murugan em frente à escadaria que leva ao templo principal das cavernas Batu. B-C) "Galeria de Arte" no complexo das cavernas Batu.

Fotos: L. Price. 
Assim como ocorre no templo principal, pequenas cavernas na base do maciço são utilizadas como espécies de galeria de arte. A primeira dessas cavernas faz parte do complexo Caverna Villa e consiste em duas cavidades repletas de estátuas hindus e painéis pintados na rocha que retratam cenas da vida dos deuses. Artesãos indianos foram trazidos até o lugar sagrado para que elaborassem as esculturas e pinturas. A Caverna de Ganesh está mais afastada no afloramento e do lado de fora está uma estátua de $15 \mathrm{~m}$ de Hanuman, o nobre macaco devoto de Lord Rama (Figura 6).
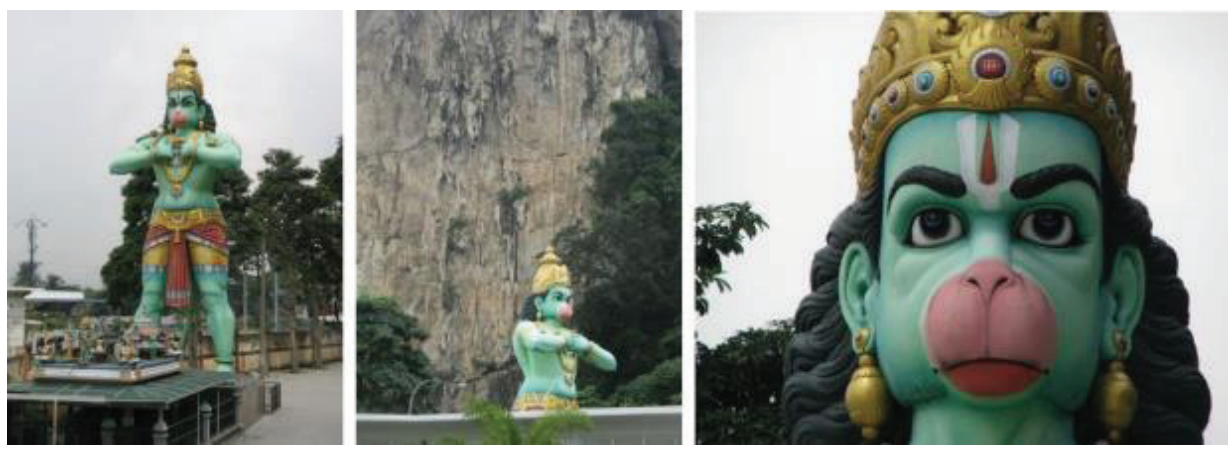

Figura 6. Detalhes da estátua de Lord Hanuman do lado de fora da caverna de Ganesh.

Fotos: L. Price.

Sobre as cavernas budistas, destaca-se que a maioria é encontrada em Perak e outras em menor quantidade, em Pahang e ao norte de Kuala Lumpur. A capital de Perak, Ipoh, é bem conhecida por suas cavernas-templo. O vale do rio Kinta, que se estende cerca de $20 \mathrm{~km}$ em direção ao norte e ao sul desta capital, possui cerca de 47 torres calcárias e mais de 35 cavernas utilizadas como templos Taoístas ou Budistas. Muitas delas foram estabelecidas há muitos anos atrás, enquanto outras são fenômenos mais recentes. $\mathrm{O}$ exemplo mais antigo é o templo Taoista de Loong Tow Ngam on Gunung Lang, erigido em meados do século XIX. Diversas deidades são cultuadas, entre elas, Tai Shang Lao Jun, deificação de Lao Zi, fundador do Taoismo. Os remanescentes de uma antiga casa de madeira podem ser vistos no local. Entretanto, é possível que seja deteriorada nos próximos anos visto que a visitação ao templo tem reduzido drasticamente nas últimas duas décadas.

Ao sul de Ipoh, em Guung Lanno, existe o templo de Kong Fook Ngam, estabelecido em 1884 (Figura 7), embora os mais famosos e conhecidos sejam os templos de Perak Tong e Sam Poh Tong. O primeiro foi fundado em 1926 e é famoso por suas paredes pintadas e esculpidas. São cerca de 200 pinturas representando dragões, fênix e outras figuras da mitologia chinesas (Figura 8). A maior pintura da caverna, com cerca de 21 metros, é a da Deusa da Misericórdia e que foi pintada por um famoso artista de Taiwan. Em uma parede no interior da caverna principal existe uma pintura de Bodhisattva. 

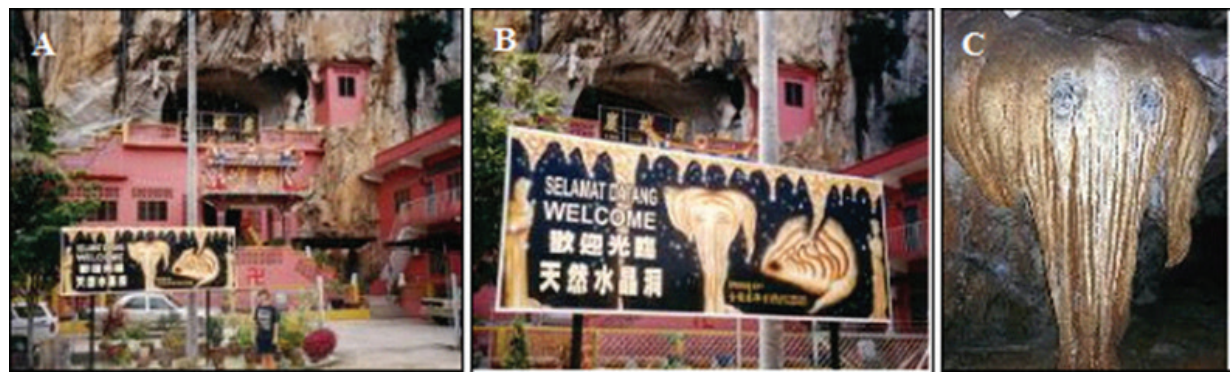

Figura 7. A) Entrada do templo Kong Fook Ngam. Como em diversas cavernas sagradas no mundo, as paredes do templo são construídas aproveitando a própria rocha calcária. B) No centro da placa é possível ver um espeleotema que "recebeu" dois olhos a fim de se parecer com a imagem de um elefante que é mostrado em ' $\mathrm{C}$ '.

Fotos A-B: L. Price; Foto C: Diana Yeoh.
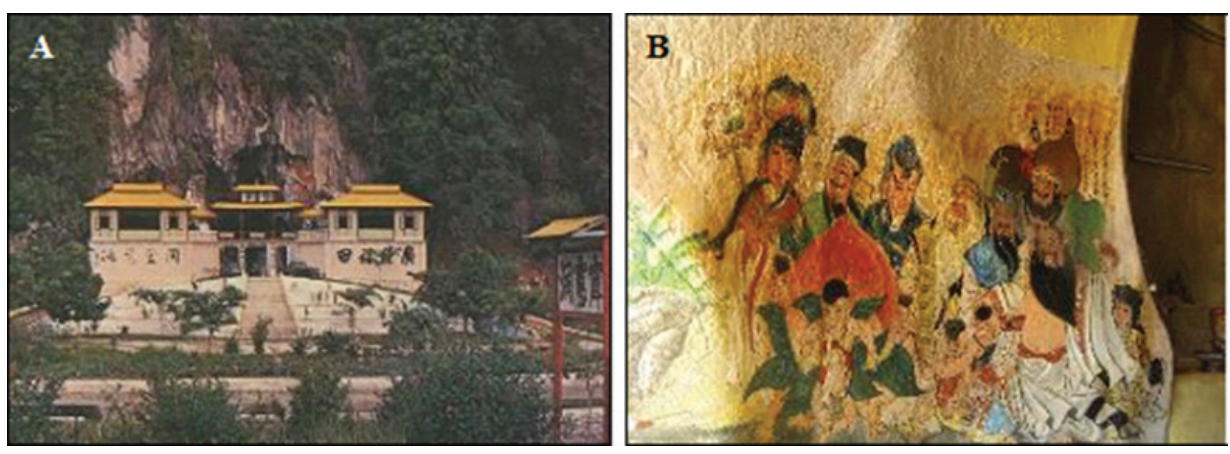

Figure 8. A) Antigo postal mostrando a entrada para a caverna-templo de Perak.

B) Parede pintada com os "Oito Imortais", cena da mitologia chinesa na caverna de Perak, Malásia.

Foto A: Acervo particular; Foto B: L. Price.

Destaca-se que os salões homenageiam diferentes deidades que chegam ao número de 50 estátuas, inclusive uma do Buda Sakyamuni medindo 15 metros e um Buda Maitreya. Essa última imagem foi destruída por causa de um abatimento do teto da caverna em 2009. No evento uma pessoa foi morta e muitas pinturas foram destruídas. Entretanto, a caverna foi rapidamente reaberta, provavelmente para atrair fieis a fim de ajudar nos esforços de restauração. Fora da caverna existe um lago de lótus e uma grande estátua da Deusa da Misericórdia.

Sobre o Templo de Sam Poh Tong (Figura 9), destaca-se que é menor, mas mais conhecido por seu lago repleto de tartarugas, animal que, na medicina tradicional malaia, é capaz de espantar os fantasmas e na mitologia chinesa, simboliza a longevidade, poder e tenacidade. Em épocas mais recentes os visitantes soltavam as tartarugas no lago a 
fim de acumular mérito, entretanto, tal prática foi proibida devido à superpopulação de animais.
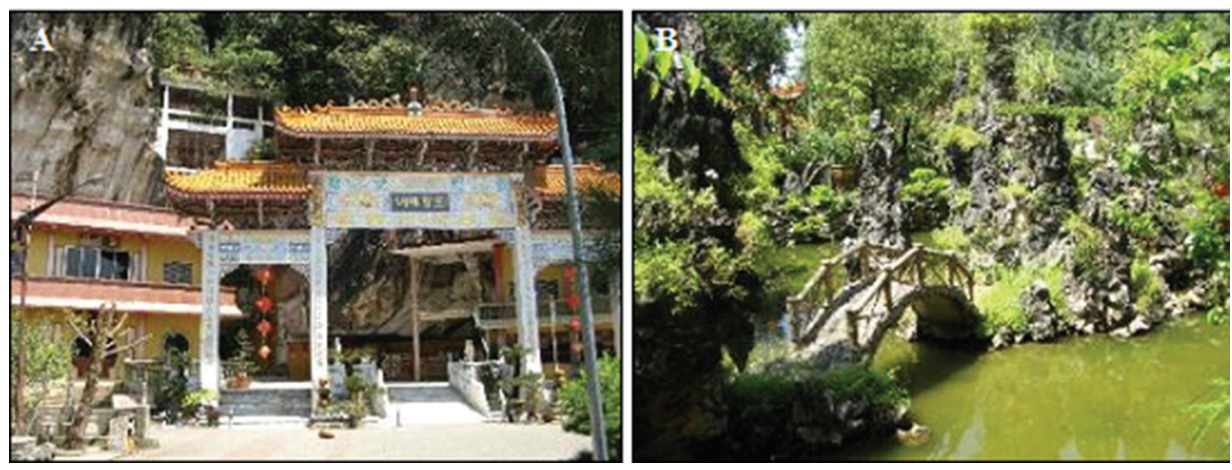

Figura 9. Detalhe da entrada do tempo de Sam Poh Tong (A) e do lago das tartarugas em 'B'.

Fotos: L. Price.

Sam Poh Tong é um dos cinco templos próximos uns aos outros em Gunung Rapat. O templo vizinho de Nam Thean Tong foi erigido em 1867 (Figura 10). O templo de Kek Look Tong é um dos mais novos e, também, o mais opulento. As paredes da caverna são revestidas de mármore e apresenta grandes estátuas douradas. Outro templo, o Kwan Yin Tong, possui mais de 75 estátuas de Kwan Yin (Deusa da Misericórdia) dentro dos limites do templo, mas existem planos para aumentar o número para 300 estátuas (Figura 11). O tempo adjacente, Da Seng Ngan, foi coberto por um deslizamento de terra em 1974 e somente redescoberto em 2006. Desde então, foi "reativado" e apresenta inúmeras estátuas douradas de Buda.
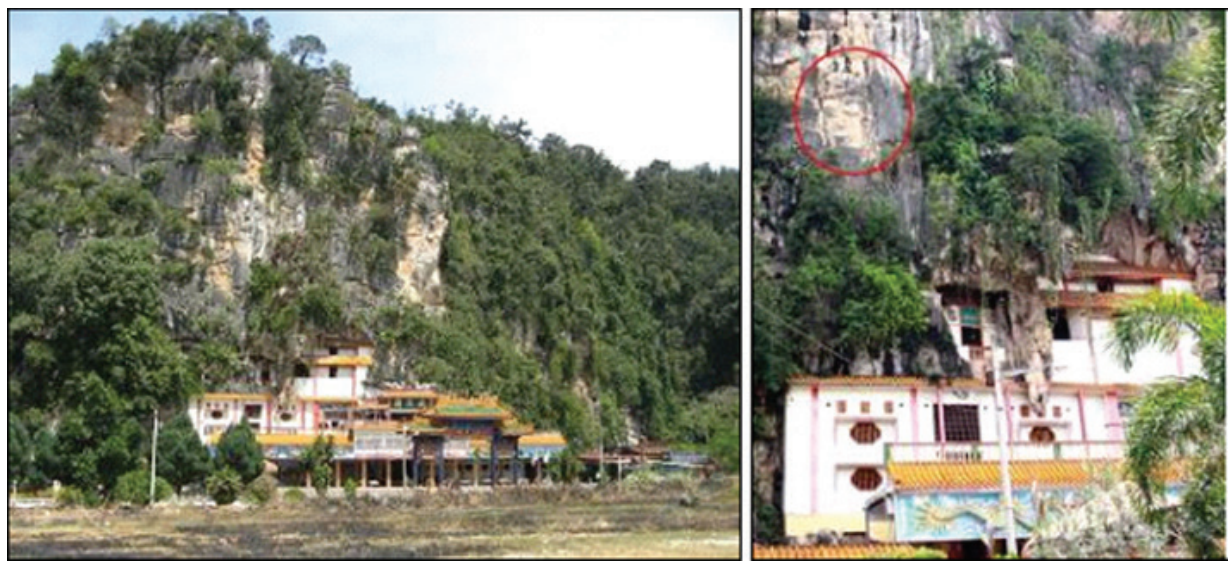

Figura 10. Detalhe da estrutura do templo de Nam Thean Tong e da imagem de Buda esculpida no paredão calcário. A imagem está circulada na foto para identificação.

Fotos: L. Price. 

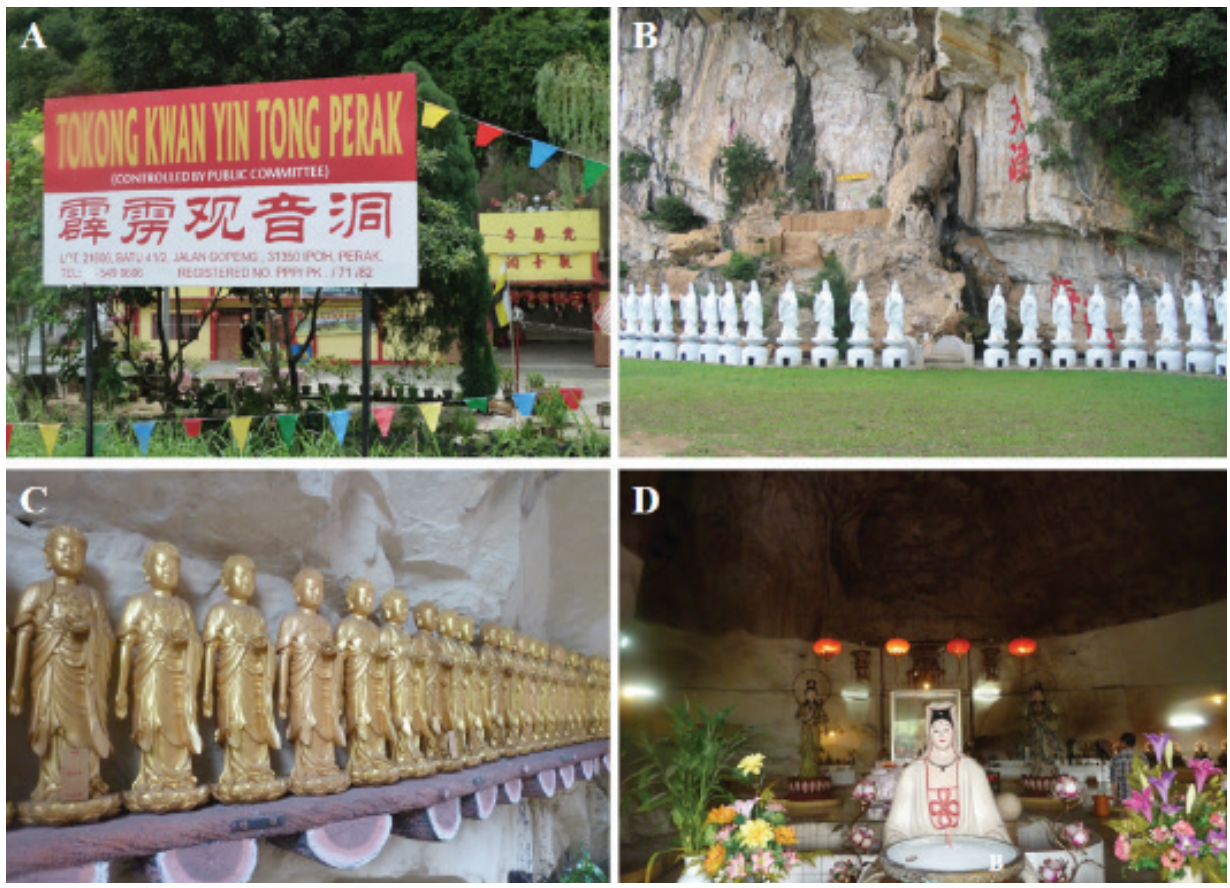

Figura 11. A) Entrada do templo com placa indicando a administração por um comitê público.

B) Estátuas da Deusa da misericórdia no templo de Kwan Yin Tong.

C-D) Estátuas no interior da caverna-templo.

Fotos: L. Price.

Em alguns templos as paredes e o teto são revestidos por fuligem oriundas das lamparinas de óleo e da queima de incensos trazidos pelos visitantes. Outros templos apresentam crematórios e columbários para guardar as urnas funerárias, sejam fora ou dentro do templo. Os praticantes acreditam que essa prática permite às famílias o retorno constante ao templo para a condução de rituais ancestrais. Os columbários ficam cheios de visitantes no Dia de Finados chinês e nos Festivais de Qing Ming e Cheng Beng que normalmente ocorre em abril. Durante os festivais os visitantes deixam oferendas na forma de comida e outros itens feitos em papel para seus familiares sendo, atualmente, uma experiência muito comercial, pois as famílias trazem réplicas em papel de itens considerados "essenciais" para a vida moderna, tais como telefones celulares, televisões, refrigeradores, computadores e carros. No passado era comum somente o uso de incensos e mel como oferendas.

$\mathrm{Na}$ Malásia ainda é possível observar o uso de cavernas para a adoração de deidades de diversas crenças. Uma caverna próxima a Ipoh é dedicada à Sai Baba, mas também abriga imagens Budistas, Hindus, Taoístas e Católica (Figura 12). Nos últimos cinco anos algumas cavernas foram sacralizadas por monges budistas e freiras oriundos da Tailândia. Assim sendo, muitas das imagens de Buda existentes nestes novos templos 
refletem o estilo Tailandês. Em Pahang a caverna templo mais famosa é Gua Charas, localizada $25 \mathrm{~km}$ a noroeste de Kuantan. O templo possui um grande Buda reclinado, além de um templo Hidu
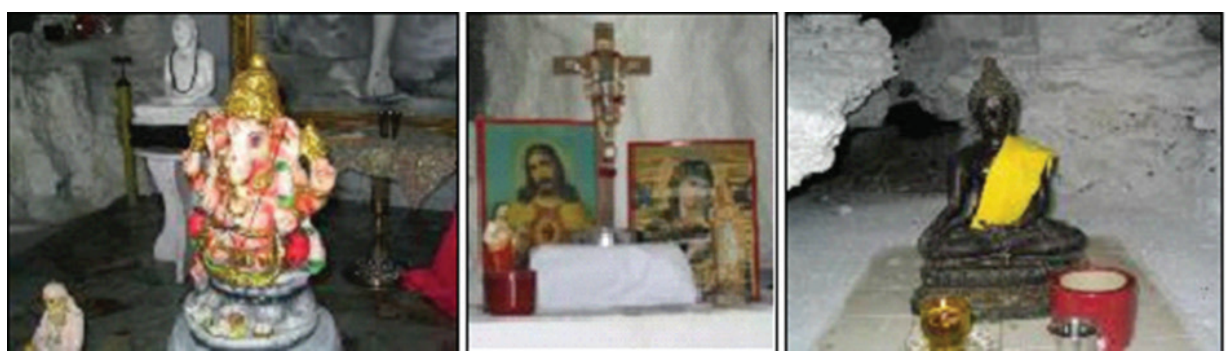

Figura 12. Exemplos de imagens Hindus, Católicas e Budistas, respectivamente, na caverna Sai Baba, Perak, Malásia.

Fotos: L. Price.

\section{Camboja}

No Camboja a maioria da população é budista, embora o país apresente antigas influências Hindus como é possível comprovar com os templos de Angkor. Em relação às cavernas, a maioria delas reflete a influência Budista. Existem muitas cavernas na província de Battambang, noroeste do país. Destas, várias são templos desta religião. Em muitos afloramentos calcários é comum observar mosteiros, bem como monges que servem de guias nas cavernas que são usadas para meditação ou abrigo na região (Figura 13). Além do uso cultural moderno, muitas cavernas-templo no país possuem importância arqueológica. Várias delas são budistas, embora a caverna Vishnu (em Phnom Sampeau) abrigue estátuas Hindus.

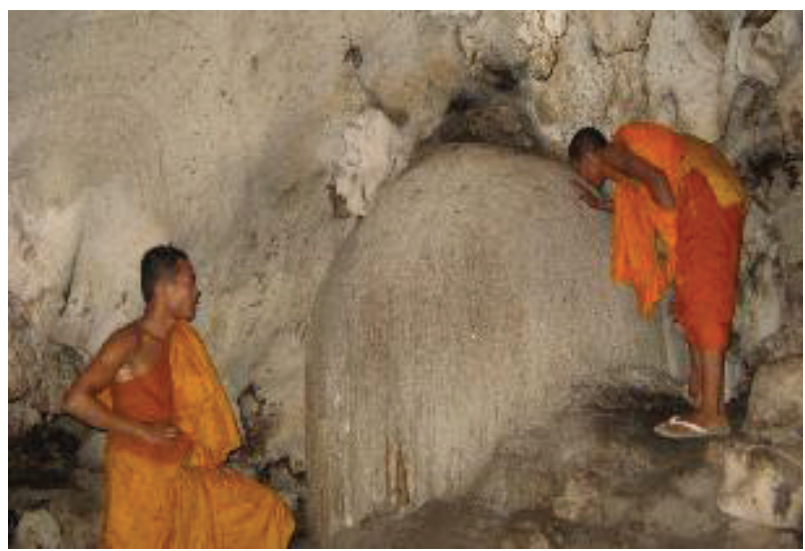

Figura 13. Monges explorando uma caverna em Battambang, Camboja.

Foto: L. Price. 
Algumas das cavernas de Battambang ficaram conhecidas como Cavernas da Morte (Killing caves) pelo fato de milhares de pessoas terem sido assassinadas pelo Khmer Vermelho, entre 1975-1979. Phnom Sampeau é um grande afloramento calcário que se destaca em meio a uma planície cárstica. Aí encontram-se três cavernas utilizadas por Pol Pot e seu regime ditatorial para matar pessoas que eram levadas para o local e, a exemplo das "cavernas da morte" da Eslovênia, Croácia e Bósnia e Herzegovina (TRAVASSOS, 2009; LUĆIĆ; TRAVASSOS, 2010), tinham suas mãos amarradas, eram vedadas e jogadas para dentro da caverna pelos seus abismos de entrada. Aqueles que porventura sobreviviam à queda definhavam até a morte por não conseguirem escapar. Sabe-se que os adultos eram mortos em cavernas separadas daquelas utilizadas para matar crianças. Por muitos anos tais cavernas abrigavam as pilhas de ossos das vítimas que hoje estão organizadas em uma estupa no interior de uma das cavernas (Figura 14).

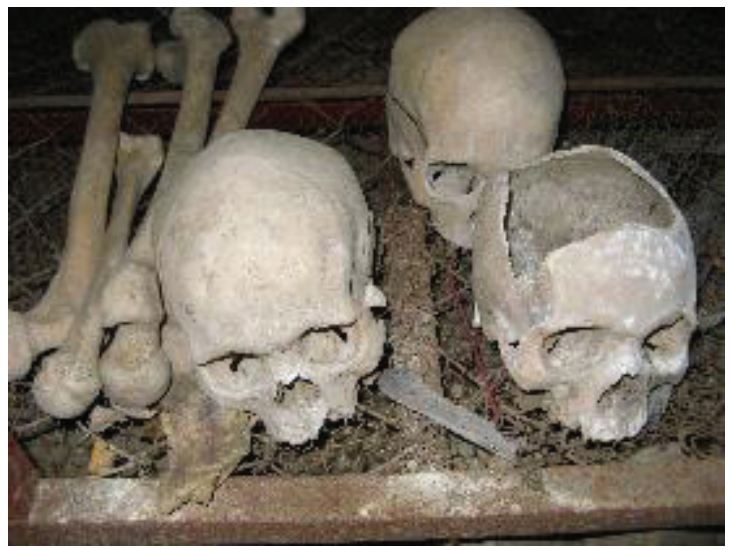

Figure 14. Lembrança das atrocidades cometidas pelo Khmer Vermelho nas Killing Caves do Camboja, em Battambang.

Foto: L. Price.

Durante o período de domínio do Khmer Vermelho, Pol Pot decretou a destruição de muitas estátuas budistas. Entretanto, hoje em dia, em Phnom Sampeau, observa-se o crescimento do número de estátuas de Buda, estupas e templos que vem sendo construídos com o dinheiro de doações. Em 2004 teve início a construção de um Buda de 38 metros de altura na base do maciço. Uma caverna em Phnom Badak, no distrito de Rattanak Mondol, é utilizada pelos habitantes durante as festividades do Ano Novo. A caverna, que possui cerca de 304 metros, é basicamente composta por dois salões separados por uma claraboia. Em outras cavernas, embora não existam templos construídos, diversas pessoas depositam oferendas e ascendem incensos.

\section{Myanmar}

Embora várias religiões sejam praticadas em Myanmar, cerca de 90\% da população é budista. Existem algumas cavernas-templo que são bem conhecidas por 
se tratarem de sítios arqueológicos. Tais exemplos são a caverna de Pindaya, no Estado de Shan State, e a caverna de Kaw Gon, no Estado de Kayin. Outras cavernas já eram conhecidas pelos estrangeiros durante o período colonial em fins do século XIX e início do XX. Entretanto, quando Myanmar (ou Burma como era chamada à época) efetivamente fechou as portas aos estrangeiros, não era mais fácil viajar pelas áreas cársticas do país. Ainda hoje algumas áreas continuam inacessíveis.

As cavernas de Pindaya, próximas à cidade de mesmo nome, são um importante centro de peregrinação budista, bem como significativas atrações turísticas. Arqueólogos mapearam a caverna principal em 1980 e identificaram mais de 8.000 imagens de Buda. Algumas delas apresentam inscrições que datam do século XIX. Uma extensa escadaria coberta, e até mesmo um elevador instalado mais recentemente, leva os visitantes ao templo principal.

Durante o período colonial, a Caverna Kaw Gon, localizada no sudeste do país (Estado de Kayin) era conhecida como a Caverna de Kogun. É também chamada de a Caverna dos Dez Mil Budas e é considerada um importante santuário budista e sítio arqueológico do século VII que somente foi visitada por estrangeiros em janeiro de $1827^{1}$. Na verdade, a caverna é mais um abrigo sob rocha do que uma caverna extensa propriamente dita. O paredão do afloramento é quase totalmente coberto de placas de argila e existem Budas por toda a área. Além disso, existe um Buda reclinado em uma construção separada. A única câmara ou salão é iluminada pela luz do dia.

Também no Estado de Kayin, tem-se a Caverna Bayin Nyi, conhecida na literatura colonial como as Cavernas de Bingyi. Temple e Oertel visitaram a caverna em abril de 1892 e Temple escreveu sobre ela em 1893. Atualmente é considerada bastante turística ou comercial, com estacionamento e outros equipamentos. Existem fontes quentes no entorno, bem como estátuas de vários tipos e cores. Escadas levam os visitantes da base do maciço até a Caverna Bayin Nyi. O interior possui um caminho de concreto até o final da caverna que guarda mais imagens de Buda. Assim como outras cavernas-templo em Myanmar, é possível identificar grafites nas paredes.

A cidade de Hpa An, capital do Estado de Kayin, é cercada por afloramentos calcários que podem chegar a até 722 metros de altura como no caso da Zwegabin Hill. Como em várias outras do Sudeste Asiático, é possível observar estupas ao longo da colina e um caminho até o topo. A Caverna Kaw Ka Taung se localiza em Kaw Kyaik, leste da colina Zwegabin. No local existe uma longa fila de monges de pedra do lado do complexo e, mesmo com apenas 53 metros de projeção horizontal, é repleta de estátuas de Buda.

No sudeste de Hpa An, é possível visitar a Caverna Saddan (Elefante Real), um templo bem conhecido no país. Na base da escadaria que leva o visitante à caverna, é possível observar duas estátuas de elefantes. O salão inicial abriga um grande Buda reclinado, bem como outras estátuas e placas douradas nas paredes. Deste salão, outros degraus levam os visitantes a uma passagem superior ao longo do maciço até um salão de

1. Pesquisador John Crawfurd. 
grandes dimensões com uma grande estalagmite que é iluminada pela luz do dia. Outros degraus levam os visitantes em direção a um lago na parte inferior.

Em Mawlamyine, cidade antes conhecida como Moulmein, no Estado de Mon, localizam-se as cavernas Farm e Kayon Gu (Ka-yon ou Payon). A Caverna Farm, com cerca de 300 metros de projeção horizontal, é repleta de estátuas de Buda. Logo na entrada os visitantes passam por um caminho de estátuas alinhadas que os levam a um grande salão $(60 \mathrm{~m}$ x $60 \mathrm{~m}$ x $60 \mathrm{~m}$ ) que é dividido por grandes blocos abatidos. Os grafites nas paredes datam de 1880 .

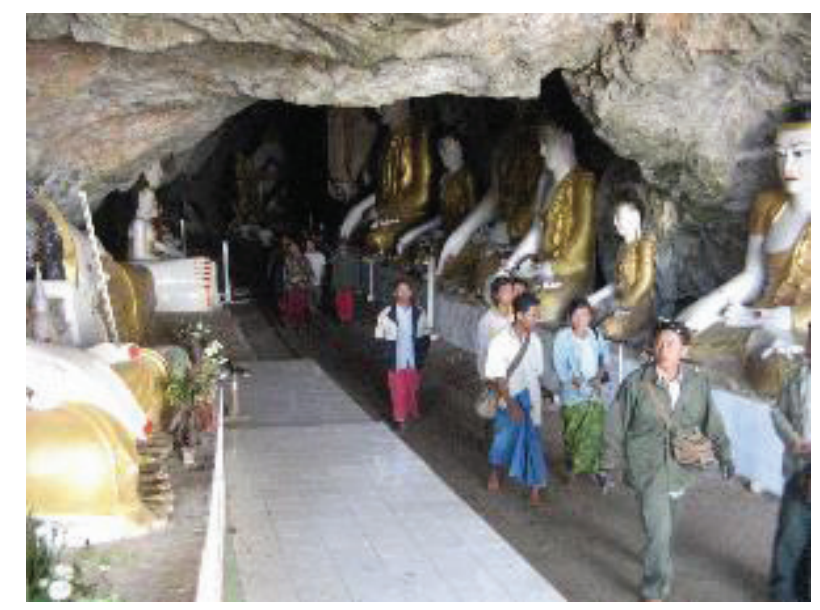

Figura 15. Estátuas de Buda na caverna Farm, em Myanmar. Foto: L. Price.

\section{China}

Com uma história conhecida de pelo menos 4.000 a.C. devido aos vestígios arqueológicos encontrados ao longo do rio Amarelo, nos círculos acadêmicos da carstologia ou da espeleologia, a China é conhecida como um país que detém importantes e expressivos exemplos de carste tropical e, obviamente, igualmente extenso uso cultural e religioso.

Para Shaw (2004), o conhecimento sobre a paisagem cárstica do país ocorre justamente por sua antiguidade indo até meados do século XVII, seguido por um longo intervalo até após a Segunda Guerra Mundial. Mesmo assim, destaca-se em 1920 a descoberta do "Homem de Pequim", na Caverna Zhoukoudian, comprovando mais uma vez o uso das cavernas desde os tempos mais remotos.

Do ponto de vista físico, devido à sua extensão continental, o país possui exemplos de carste em regiões alpinas (ou de montanha), áridas e semiáridas, tropicais e subtropicais, bem como exemplos no litoral. De acordo com a abordagem adotada neste trabalho, destacam-se alguns dos exemplos encontrados na região de Guilin (Guangxi) 
e seu entorno. Na região, de acordo com o IRCK (2013), os traços mais antigos da ocupação humana datam da Dinastia Qin (221-206 a.C.), época em que ocorreu o longo e difícil processo de unificação das populações que viviam no vasto território chinês (SCARPARI, 2006). Na cidade de Guilin, atualmente, ainda é possível identificar os traços da ocupação humana desde as Dinastias Tang (618-907 d.C.), Song (960-1279 d.C.), Ming (1368-1644) e Qing (1644-1911) e alguns serão identificados a seguir:

\section{- Solitary Beauty Peak}

Essa feição é a torre calcária que se localiza no parque Cidade do Príncipe Jingjiang, no centro de Guilin. A área protegida foi o local de moradia desse príncipe durante a Dinastia Ming (1368-1644) e representa espaço de cultura e história da cidade. A mansão levou cerca de vinte anos para ser construída, ocupa uma área de 19.78 hectares e nos cerca de 257 anos que envolveram a construção e destruição da cidade fortificada, abrigou 14 príncipes regionais em 12 gerações que viveram no local. Na Dinastia Qing (1644-1911) serviu como local de testes acadêmicos (Figura16).
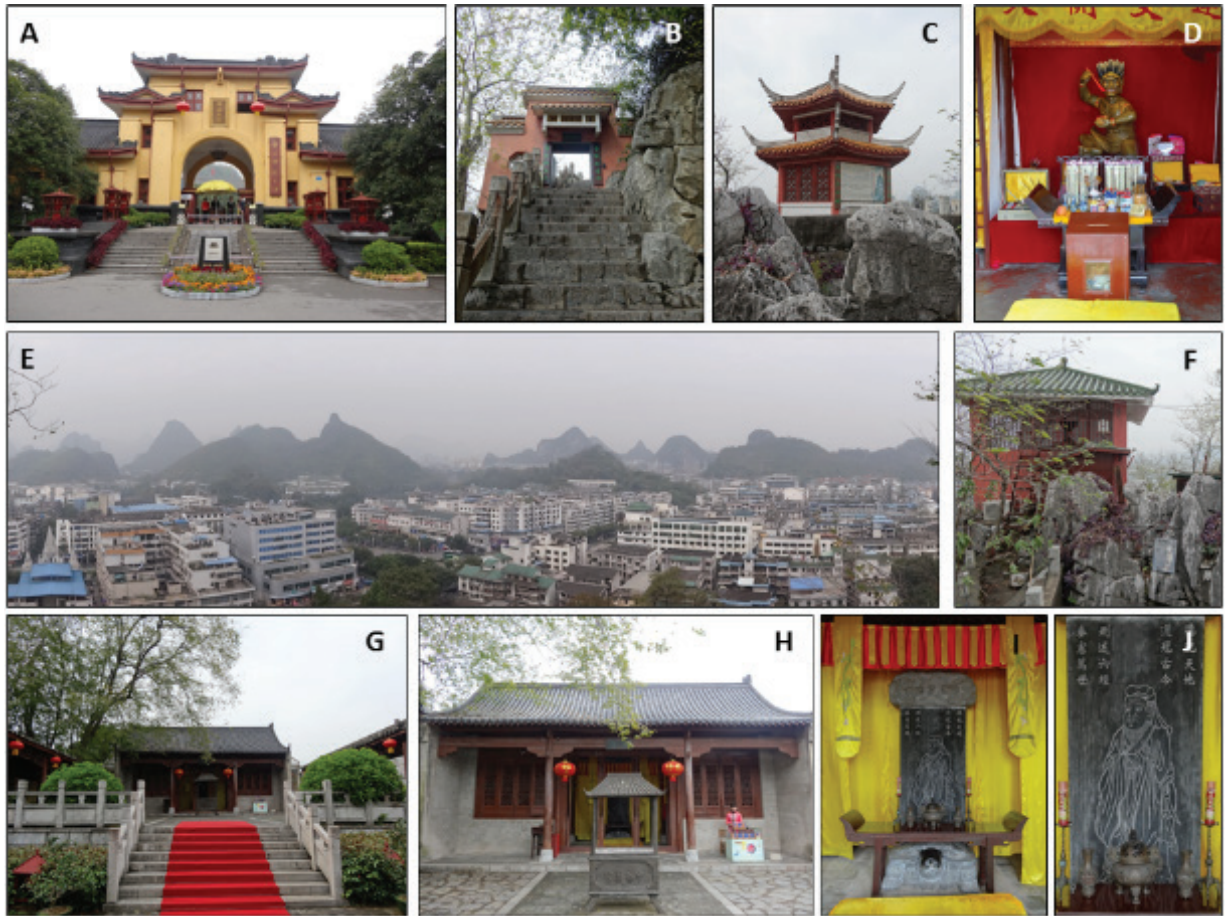

Figura 16. A) Entrada da Cidade do Príncipe Jingjiang. Sua organização espacial lembra a Cidade Proibida em Pequim. B) Escadas de acesso ao topo do Solitary Beauty Peak. C-D)

Detalhes de um dos templos localizados no topo da torre. E) Visão panorâmica da cidade de Guilin a partir do topo. F) Detalhe de mais um templo no alto da torre calcária. G-H) Detalhes do acesso e entrada do Templo de Confúcio. I-J) Detalhes do altar dedicado a Confúcio.

Fotos: L. E. P. Travassos. 
A torre em questão possui cerca de 66 metros de altura, sendo um dos pontos mais importantes da cidade. Recebeu seu nome durante a Dinastia do Sul (420-589) quando na literatura da época foi dito que nada nem ninguém poderia superar este pico solitário em beleza. Cerca de 306 degraus levam o visitante ao topo da torre que guarda pequenos templos. Outras pequenas cavernas existem dentro dos limites desta cidade fortificada. São elas a Caverna da Paz e a Caverna da Leitura. A primeira era utilizada como local de oração pelo príncipe Jingjiang e a segunda foi o lugar onde um famoso escritor da Dinastia do Sul (Yan Yanzhi) compunha e lia seus poemas enquanto era governador do condado de Shi'an, hoje, Guilin.

- Fubo Hill

Embora localizado em um pequeno parque, a torre de 213 metros de altura é similar às muitas existentes em Guilin e apresenta pelo menos duas cavernas interligadas e um abrigo sob rocha. Do ponto de vista histórico e religioso abriga um templo em homenagem a um general da Dinastia Tang (618-907) e um sino da Dinastia Qing (1644-1911). A Caverna dos Mil Budas e a Caverna das Pérolas que Retornam abrigam esculturas budistas das dinastias Tang e Song (Figura 17). Durante a Dinastia Song, do ponto de vista da geografia, destacam-se as contribuições no campo da cartografia e da geografia física e humana. Talvez Fan Chengda (1126-1193) seja o nome mais conhecido por ter se destacado no gênero da literatura de viagens.
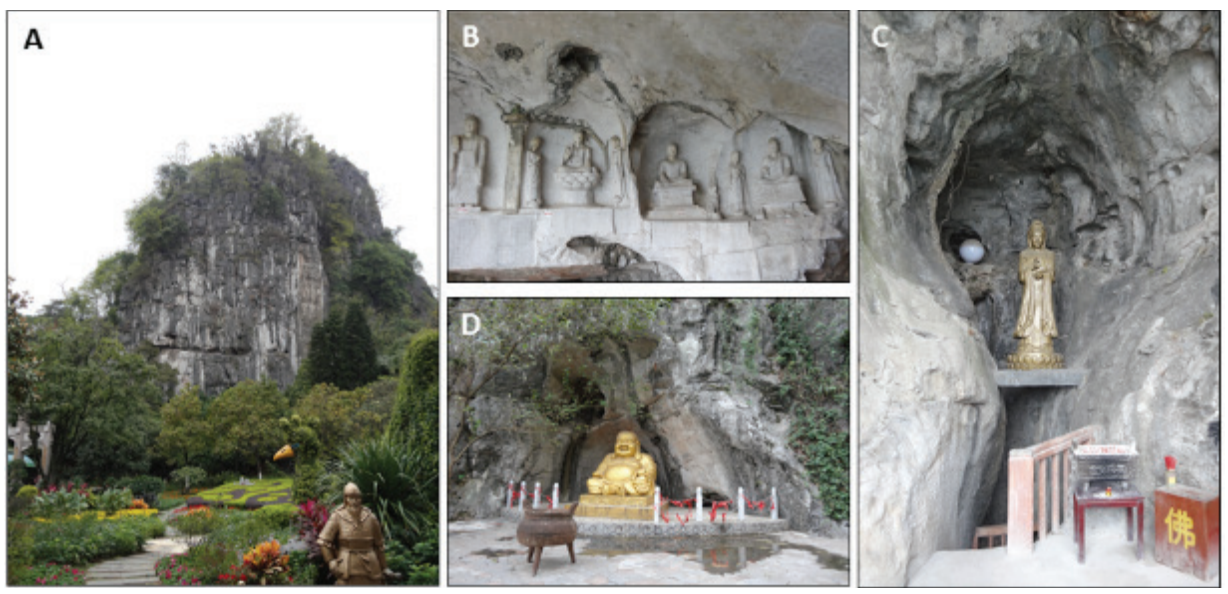

Figure 17. A) Aspecto geral da Fubo Hill. B-C) Esculturas de estátuas budistas na caverna dos Mil Budas. D) Abrigo sob rocha com imagem do Buda Hotei próximo à entrada da caverna das Pérolas que Retornam.

Fotos: L. E. P. Travassos. 
- Seven Star Cave

Embora não seja um templo religioso formal, localiza-se próximo a um templo budista no Parque das Sete Estrelas, o maior e mais conhecido da cidade de Guilin. Para entrar na caverna o visitante passa por uma pequena cavidade com estátuas de deuses que são tocadas pela maioria dos visitantes (Figura 18). Após passar pela pequena caverna, os visitantes encontram altares e podem depositar oferendas normalmente na forma de dinheiro ou bandeirolas.
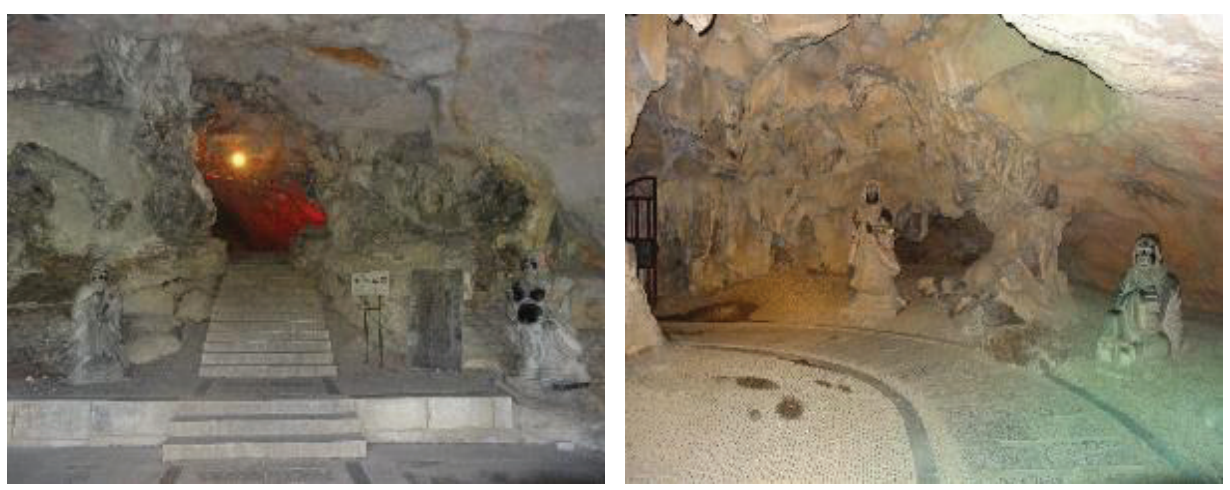

Figura 18. Aspectos gerais do caminho que leva o turista à caverna das Sete Estrelas Fotos: L. E. P. Travassos.

Segundo informações turísticas locais, os três caracteres "Xi Xia Cave" esculpidos na rocha na entrada da caverna datam do ano 590 e foram feitos durante a Dinastia Sui. Além disso, sua exploração mais antiga data da Dinastia Tang, há cerca de 1.300 anos e, por muitos anos, os moradores locais acreditavam que a caverna era residência dos imortais.

Dentro da caverna o visitante ainda pode comprar amuletos e outros produtos, bem como pagar para tocar ou tirar fotos de uma tartaruga que, conforme destacado anteriormente, é um animal considerado sagrado e simboliza longevidade, poder e tenacidade. Na mitologia chinesa, Allan (1991) destaca que a tartaruga ajudou Pangu (P'an Ku) a criar o mundo. Para Simoons (1991) e Ball (2004), a tartaruga é um dos "Quatro Fabulosos Animais" que dominam cada qual um ponto cardeal. O norte é dominado por ela simbolizando, também, resistência, força e longevidade.

Em outra entrada do parque, pelo portão nordeste, é possível visitar a Caverna de Longyin e suas inscrições históricas. Originalmente a caverna recebia o nome de Huixue e durante a Dinastia Song recebeu o nome atual. Localizada na base do terceiro afloramento ou montanha mais alta de Guilin, as inscrições datam do ano 894 d.C. e são atribuídas a Zhang Juan e Liu Songgui que registraram na entrada informações políticas, econômicas, culturais e militares na forma de poemas, poesias e imagens (Figura 19). No interior da caverna são distribuídas 41 estátuas de Buda e no salão principal três 
grandes estátuas do Buda sentado sobre um trono de lótus. Além dessas imagens é possível identificar, mas não fotografar, imagens de Maitreya (Deusa da Misericórdia) e Wei Tuo, ou Skanda, conhecido como o guardião dos mosteiros e templos budistas e seus ensinamentos. Próximo à caverna o visitante também pode visitar um pequeno abrigo sob rocha com outras estátuas budistas, bem como inscrições na rocha (Figura 20).
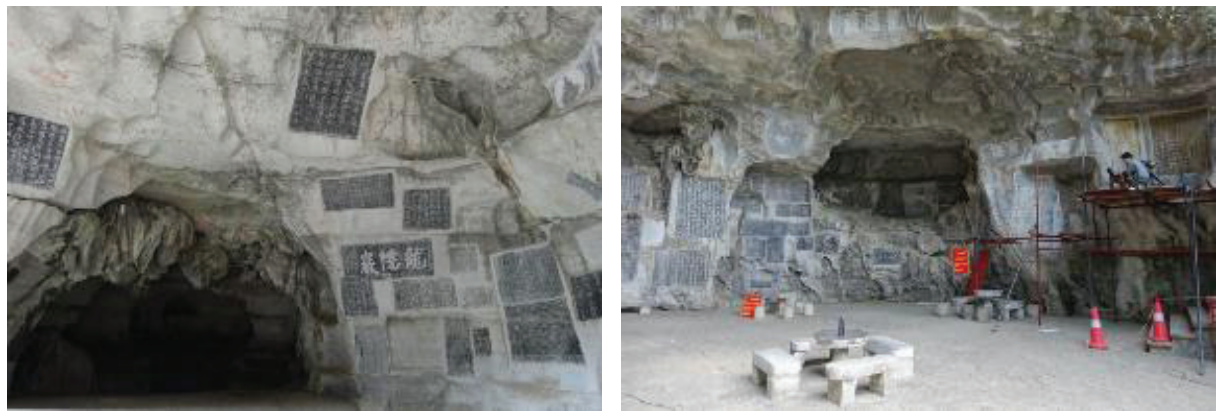

Figura 19. Detalhes das localização das inscrições próximas à caverna de Longyin.

No momento da visita as inscrições estavam sendo digitalizadas por professores de uma universidade de Guilin.

Fotos: L. E. P. Travassos.
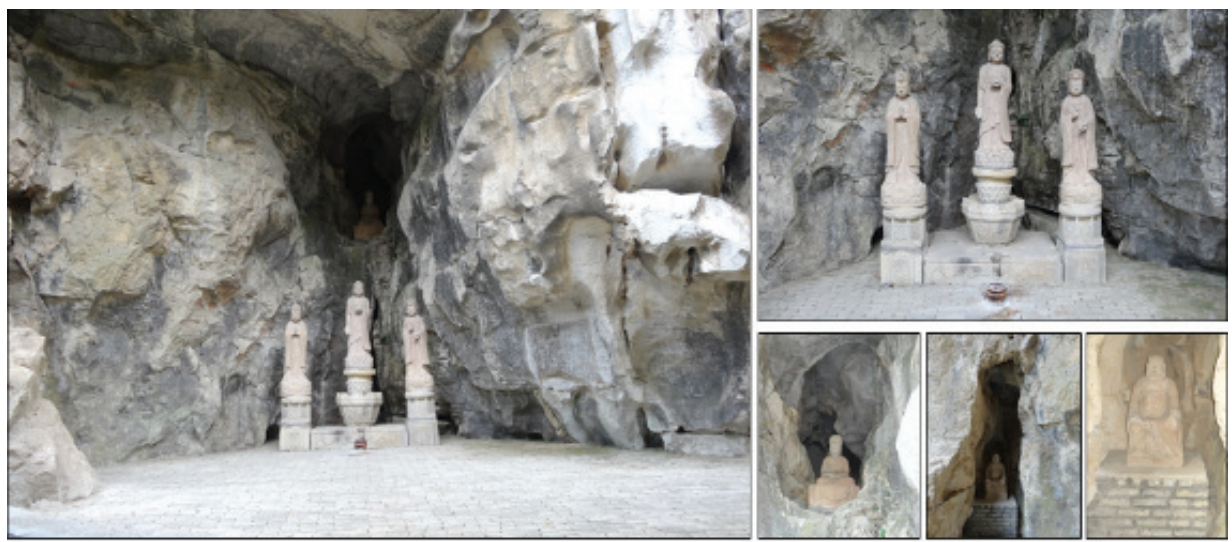

Figura 20. Aspectos gerais das imagens budistas próximas à caverna de Longyin.

Fotos: L. E. P. Travassos.

- Chuan Shan Park

Localizado ao sul da cidade na margem oeste do rio Xiaodong (afluente do rio Li), o parque possui uma área de aproximadamente $2 \mathrm{~km}^{2}$. No local é possível identificar cavernas turísticas que possuem conotação religiosa, bem como um templo (Shou Fo 
Temple) e uma Pagoda da Dinastia Ming que é dedicada ao Buda da Longevidade e localizada no topo de uma torre cárstica.

A Caverna Tunnel Hill, localizada no afloramento de mesmo nome, possui cerca de 517 metros de projeção horizontal, sendo bem ornamentada. Para o foco deste trabalho, destacam-se pequenos altares destinados a deuses da mitologia chinesa. Embora o foco da visita não seja exclusivamente religioso, muitos turistas compram lembranças de deuses que correspondem a um animal do horoscopo chinês e à sua data de nascimento (Figura 21).
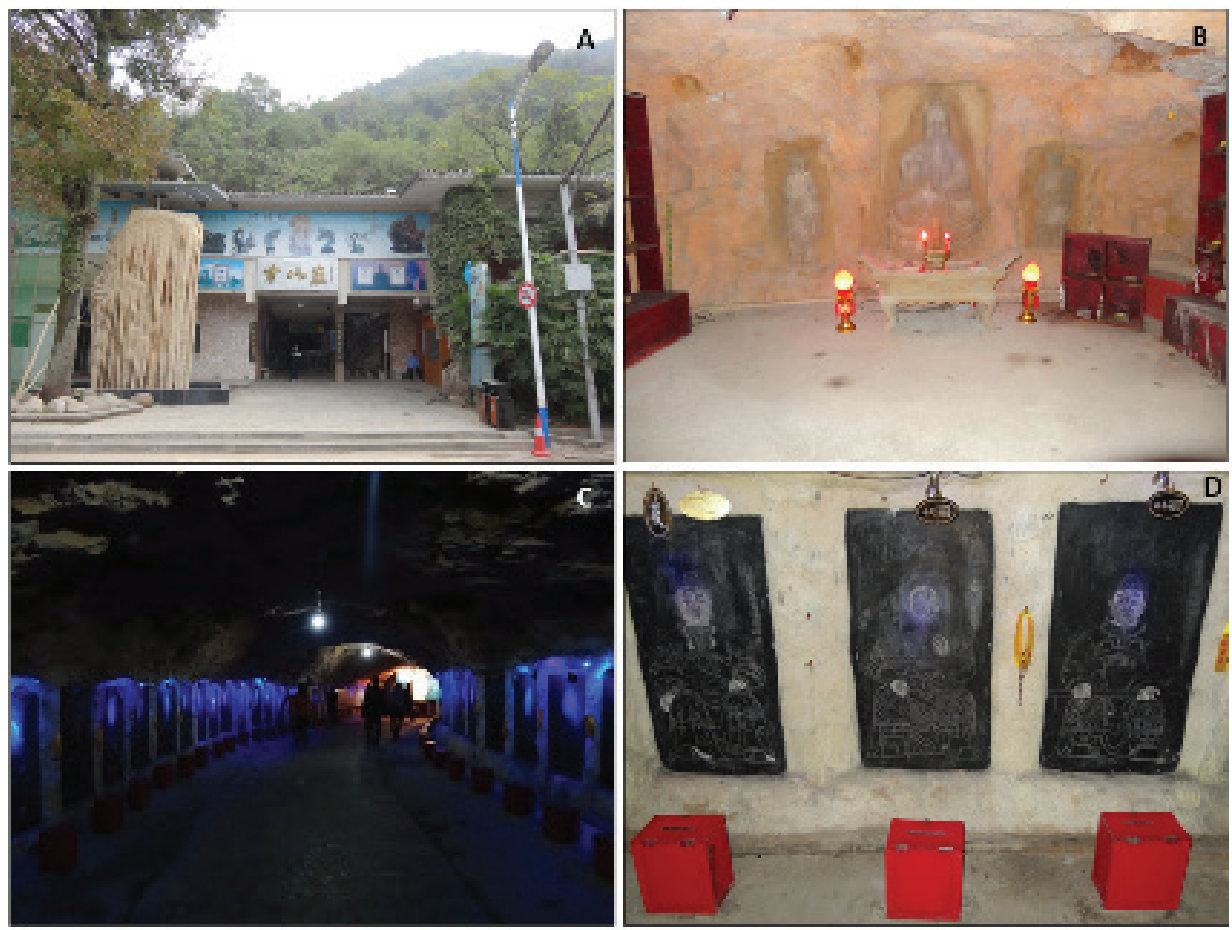

Figura 21. A) Entrada da caverna Tunel Hill. B) Um dos muitos nichos dedicados a deidades chinesas. C) Caminho que mostra deuses protetores do horóscopo chinês. D) Detalhe das imagens esculpidas em rochas externas à caverna e que foram colocadas em seu interior. Acima da imagem é possível identificar o ano do "protetor" e nas caixas vermelhas são feitas as doações em dinheiro.

Fotos: L. E. P. Travassos.

O Templo Shou Fo também é visitado neste parque. Localizado no topo de um afloramento, consiste em uma ampla caverna com estátuas e outras estruturas religiosas. Não se sabe muito sobre a história do lugar, entretanto, é notadamente um lugar sagrado (Figura 22). 

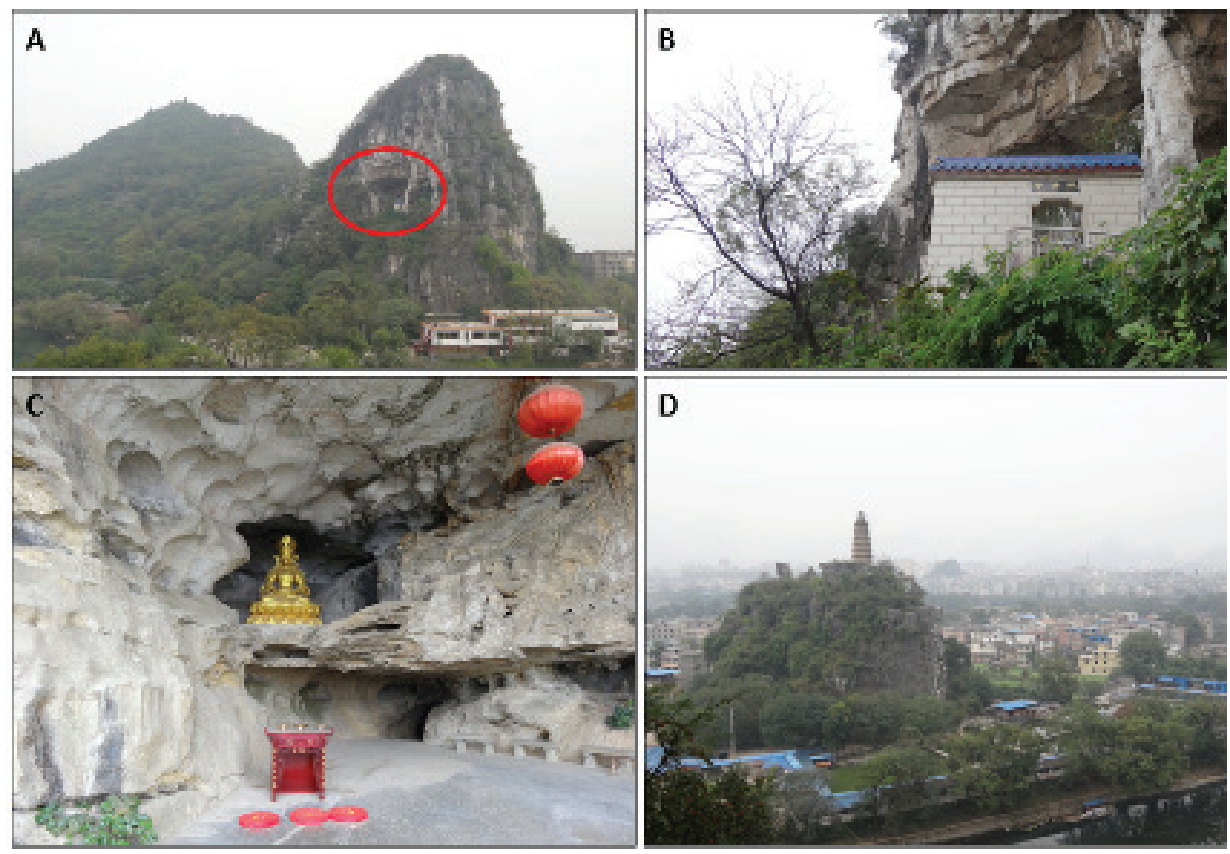

Figura 22. Detalhes do Templo Shou Fo e paisagem do entorno. A) O círculo vermelho mostra a localização do termplo no afloramento. B) Acesso ao templo em meio à mata. C) Entrada do templo com imagem budista. D) Vista da Pagoda Hill a partir do Templo Shou Fo.

Fotos: L. E. P. Travassos.

\section{Conclusões}

As cavernas-templo localizadas na Tailândia, Camboja e Myanmar são bem diferentes daquelas existentes na Malásia, especialmente no tocante ao número de Budas reclinados, outras estátuas de Buda, bem como aos protocolos de visitação. Na Malásia raramente é necessário remover os calçados para visitar os templos e na Tailândia esperase que o visitante remova os calçados ao chegarem próximo ao templo principal. Já em Myanmar os visitantes devem remover seus calçados dentro de todo o complexo sagrado. Destaca-se que a exceção à regra são as expedições espeleológicas onde se permite o uso de calçados uma vez que se passa a área central, ou como diria Mircea Eliade, o "centro do mundo" sagrado. Na China, em muitas cavernas-templo, não é preciso retirar os calçados, embora seja possível avistar praticantes realizando tal ato.

Embora os países abordados neste trabalho sejam considerados relativamente pobres em escala mundial, especialmente em áreas rurais, não parece existir falta de dinheiro para ser gasto nos templos. Muitos budistas acreditam que fazer doações de dinheiro ou outras oferendas é uma forma de acumular mérito e bênçãos. Também é muito comum que os jovens rapazes entrem para um mosteiro por um período de tempo. 
Assim, com algum tempo livre, muitos dos monges descobrem e exploram cavernas. Em muitas expedições espeleológicas, monges são frequentemente os guias.

Muitas montanhas e afloramentos calcários do Sudeste Asiático e China estão intensamente exploradas pela indústria cimenteira, a exemplo de várias regiões do mundo. Infelizmente alguns destes locais guardam importantes cavernas-templo que precisam ser poupadas por abrigarem importantes registros arqueológicos e etnográficos, fazendo-se necessário a busca pelo equilíbrio entre a geoconservação e o uso dos recursos naturais.

\section{Referências}

ALLAN, S. The shape of the turtle: Myth, art, and Cosmos in Early China. SUNY Press, 1991

ANNANDALE, N; COGGIN BROWN, J; GRAVELY, F. H. The limestone caves of Burma \& the Malay Peninsula. J. Proc. Asiatic Soc. Bengal, v.9, n.10, p. 391-424, 1913.

BALL, C. Animal motifs in Asian Art. Courier Dover Publications, 2004.

DUNKLEY, J. R., SEFTON, M., NICHTERLEIN, D.; TAYLOR, J. Karst and caves of Burma (Myanmar). Cave Science, v.16, p.123-131, 1989.

DINIZ, A. M.; TRAVASSOS, L. E. P. ; BRANDÃO, V. S. ; RIOS, F. V. P. Some aspects of the geographical distribution of Buddhist caves. In: 16th International Congress of Speleology, 2013, Brno. Proceedings... Brno: Czech Speleological Society/ SPELEO2013/IUS, 2013. v. 1. p. 365-368.

GAARDER, J.; HELlERN, V.; NOTAKER, H. O livro das religiões. São Paulo: Companhia das Letras, 2005. Tradução de Isa Mara Lando e Revisão Técnica do Prof. Antônio Flávio Pierucci.

GEYER, E., SCHMIDT, F.; JEUTTER, P. Expedition Gunung Lanno Malaysia. Bad Mitterndorf/Austria: Verein fur hohlenkunde in Obersteier (VHO), 2005. 240p.

GILLIESON, D. ASIA, Southeast Islands. In: GUNN, John (ed.). Encyclopedia of Caves and Karst Science. New York/London: Fitzroy Dearborn, 2004. p. 210-224.

GLOVER, I.; PRICE, L. ASIA, Southeast: Archaeological Caves. In: GUNN, John (ed.). Encyclopedia of Caves and Karst Science. New York/London: Fitzroy Dearborn, 2004. p. 224-224.

GOVERNMENT of Singapore. Department of Statistics, 2013. Disponível em: $<$ https:// www.google.com/url?q=http://www.singstat.gov.sg/statistics/browse_by_theme/ population/census2010/religion.xls\&sa=U\&ei=mhHLUuSDL6WZ2QXYhIC4CQ Q\&ved

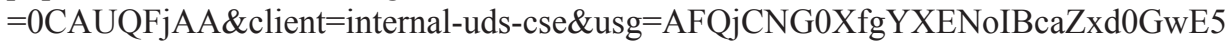
StjXhg> Acesso em 28 dez 2013

GUILIN Tourism Dicitionary. Guilin: Li Jiang Press, 1993.

HERRIES, A. Caves of the Battambang karst. Descent, n.192, p.31-32, 2006a. 
HERRIES, A. Explorations in Cambodian karst: Battambang Province North West Cambodia. Sydney University Speleological Society, v.46, p.2, p.08-13, 2006 b.

HOBBS, J. Ritual uses of caves in West Malaysia, 2004. (Artigo preparado para palestra) KIERNAN, K. Religious sites. In: GUNN, J. (Ed.). Encyclopedia of caves and karst science. London: Routledge, 2004. p.622-625.

KUSCH, H. Kult-und Tempelhohlen in West Malaysia. Die Hohle, v.34, n.4, p.148-158, 1983.

IRCK - International Research Center on Karst. Participant manual for 2013 IRCK International Training Course on Karst Hydrogeological Inverstigation, Dynamic Monitoring and Application in River Basin. Guilin/Guangxi/China: IRCK, 2013.

LAUMANNS, M. (ed.) Karst and Caves of Myanmar. Berliner Höhlenkundliche Berichte, v.39, 2010. 130p.

LAUMANNS, M.; PRICE, L. (ed.) Atlas of the Great Caves and the Karst of Southeast Asia. Berliner Höhlenkundliche Berichte, 2010 (Volumes 40 e 41).

LUĆIĆ, I.; TRAVASSOS, L. E. P. Cavernas de vida e morte no Carste Dinárico. O Carste (Belo Horizonte), v. 22, n.3, p. 97-101, 2010.

MOURET, C. ASIA, SOUTHEAST. In: GUNN, John (ed.). Encyclopedia of Caves and Karst Science. New York/London: Fitzroy Dearborn, 2004. p. 210-217.

OERTEL, F.O. Note on a Tour in Burma in March and April 1892. Reprint Bangkok: White Orchid Press, 1995. First published 1894.

PRICE, L. Burmese Buddhas. Cerberus Spel. Soc., v.16, n.6, p. 126-128, 1986.

PRICE, L. Burmese Buddhas. British Caver, n.101, p.28-30, 1987.

PRICE, L. Malaysian cave temples. Cerberus Spel. Soc. v.18, n. 4, p.99-104, 1989.

PRICE, L. Batu Caves - Thaipusam festival. Cerberus Spel. Soc., v.19, n.4, p.16-17, 1990.

PRICE, L. Malaysian cave bibliography (up to 1997). Kuala Lumpur: Gua Publications, 1998. 108p.

PRICE, L. Caves and karst of Peninsular Malaysia: a register. Kuala Lumpur: Gua Publications, 2001. 98p.

PRICE, L. Some $19^{\text {th }}$ century visitors to caves in peninsular Malaysia. Acta Carsologica, V.31, n.2, p.233-247, 2002.

PRICE, L. The killing caves of Cambodia. Axbridge CG Jnl., Jan., p 6-10, 2005.

PRICE, L. A speleotourism in peninsular Malaysia. Pesquisas em Turismo e Paisagens Cársticas (Campinas), v.1, n.2, p. 183-187, 2008.

PRICE, L. Underground in Battambang, Cambodia 2008. Speleology 13, p.8-11, 2009.

PRICE, L. Caving in Southern Myanmar. Speleology 15, 2010a. 
PRICE, L. Myanmar. In: LAUMANNS, M.; PRICE, L. (ed.) Atlas of the Great Caves and the Karst of Southeast Asia. Berliner Höhlenkundliche Berichte, 2010b (Volume 39).

PRICE, L. Karst of Southeast Asia. In: LAUMANNS, M.; PRICE, L. (ed.) Atlas of the Great Caves and the Karst of Southeast Asia. Berliner Höhlenkundliche Berichte, 2010c (Volumes 40 e 41).

PRICE, L. Barefoot amongst the Buddhas: Myanmar 2009. Speleology 16, p. 25-30, 2010d.

PRICE, L. Myanmar Geographical and geological settings; History of speleological exploration in Myanmar; Cave archaeology in Myanmar. In: LAUMANNS, M. (ed.) Karst and Caves of Myanmar. Berliner Höhlenkundliche Berichte, v.39, 2010e.

PRICE, L. Malaysian cave bibliography (up to 2012). Kuala Lumpur: Gua Publications, 2013. 248p.

PRICE, L. Caves and limestone hills of Malaysia, 2004-2013. Disponível em: <http://www.cavesofmalaysia.com> Acesso em 17 dez 2013.

PRICE, L. Caves of Myanmar, 2009-2013. Disponível em: <http://myanmarcaves.wiki dot.com> Acesso em $17 \mathrm{dez} 2013$.

PRICE, L. Caves and karst of Peninsular Malaysia. A register. 2.ed. Kuala Lumpur: Gua Publications, 2014 (no prelo)

PRICE, L.; CLUCAS, D. Malaysia. In: LAUMANNS, M.; PRICE, L. (ed.) Atlas of the Great Caves and the Karst of Southeast Asia. Berliner Höhlenkundliche Berichte, 2010 (Volume 41)

PRICE, L.; LAUMANNS, M. Myanmar. In: LAUMANNS, M.; PRICE, L. (ed.) Atlas of the Great Caves and the Karst of Southeast Asia. Berliner Höhlenkundliche Berichte, 2010 (Volume 41)

ROBINSON, B. A. Numbers of adherents of major religions, their geographical distribution, date founded, and sacred texts. In: Religious Tolerance: Ontário Consultants on Religious Tolerance, 2011. Disponível em: <http://www. religioustolerance.org/worldrel.htm>. Acesso em 10/12/2013

SCARPARI, M. A China Antiga. Barcelona: Ediciones Folio, 2006.

SIMOONS, F. J. Food in China: a cultural and historical inquiry. CRC Press, 1991.

SHAW, T. ASIA, NORTHEAST: HISTORY. In: GUNN, John (ed.). Encyclopedia of Caves and Karst Science. New York/London: Fitzroy Dearborn, 2004. p. 204-209.

SWEETING, M. M. The Guilin Karst, Z.Geomorph. N.F. (Berlin-Stutgart), Suppl.-Bd. 77, p. 47-65, Februar 1990.

TEMPLE, R. C. Notes on Antiquities in Ramannadesa (The Talaing Country of Burma). Reprinted from the Indian Antiquary. Bombay: Education Society's Steampress, 1894 
TRAVASSOS, L. E. P. O Abismo Šemonovo (Šemonovo Brezno) e seu uso no período pós-guerra. In: VIII Encontro Nacional da ANPEGE, 2009, Curitiba. Encontro Nacional da ANPEGE. Curitiba: ANPEGE, 2009. p. 1-13.

WALTHAM, T. Fengcong, fenglin, cone karst and tower karst. Cave and Karst Science, v.35, n.3, p. 77-88, 2008.

WALTHAM, T.; EAVIS, A. Caves in Myanmar. Cave and Karst Science, v.31, n.1, p.3-6, 2004.

YEOH, D. On the trail of Ipoh's cave temples, New Straits Times, 2013. Disponível em: $<$ http://www.nst.com.my/latest/on-the-trail-of-ipoh-s-cave-temples-1.205790> Acesso em 16 dez 2013.

YUAN, D. Karst of China. Geological Publishing House: Beijing/China, 1991.

Liz PRICE

Espeleóloga representante da Malásia na União Internacional de Espeleologia (UIS). Kuala Lumpur, Malásia.

E-mail: lizprice@hotmail.com

Luiz Eduardo Panisset Travassos

Doutor em Geografia pela PUC-Minas e doutor em Carstologia pela Universidade de Nova Gorica, Eslovênia. Atualmente é Professor do Programa de Pós-Graduação em Geografia da PUC Minas.

Av. Dom José Gaspar n. 500 - Coração Eucarístico

30535-610 - Belo Horizonte, MG - Brasil

E-mail: luizepanisset@gmail.com

Recebido para publicação em dezembro de 2015

Aprovado para publicação em março de 2016 